\title{
Post-VX exposure treatment of rats with engineered phosphotriesterases
}

\author{
Lisa Stigler ${ }^{1} \cdot$ Anja Köhler ${ }^{1,2} \cdot$ Marianne Koller $^{1} \cdot$ Laura Job $^{2} \cdot$ Benjamin Escher $^{2} \cdot$ Heidrun Potschka $^{3}$. \\ Horst Thiermann ${ }^{1} \cdot$ Arne Skerra $^{2} \cdot$ Franz Worek $^{1} \cdot$ Timo Wille $^{1} \mathbb{C}$
}

Received: 25 October 2021 / Accepted: 9 December 2021 / Published online: 28 December 2021

(c) The Author(s) 2021

\begin{abstract}
The biologically stable and highly toxic organophosphorus nerve agent (OP) VX poses a major health threat. Standard medical therapy, consisting of reactivators and competitive muscarinic receptor antagonists, is insufficient. Recently, two engineered mutants of the Brevundimonas diminuta phosphotriesterase (PTE) with enhanced catalytic efficiency $\left(k_{\text {cal }} / K_{\mathrm{M}}=21\right.$ to $38 \times 10^{6} \mathrm{M}^{-1} \mathrm{~min}^{-1}$ ) towards $\mathrm{VX}$ and a preferential hydrolysis of the more toxic $\mathrm{P}(-)$ enantiomer were described: PTEC23(R152E)-PAS(100)-10-2-C3(I106A/C59V/C227V/E71K)-PAS(200) (PTE-2), a single-chain bispecific enzyme with a PAS linker and tag having enlarged substrate spectrum, and 10-2-C3(C59V/C227V)-PAS(200) (PTE-3), a stabilized homodimeric enzyme with a double PASylation tag (PAS-tag) to reduce plasma clearance. To assess in vivo efficacy, these engineered enzymes were tested in an anesthetized rat model post-VX exposure $\left(\sim 2 \mathrm{LD}_{50}\right)$ in comparison with the recombinant wild-type PTE (PTE-1), dosed at $1.0 \mathrm{mg} \mathrm{kg}^{-1}$ i.v.: PTE-2 dosed at $1.3 \mathrm{mg} \mathrm{kg}^{-1}$ i.v. (PTE-2.1) and $2.6 \mathrm{mg} \mathrm{kg}^{-1}$ i.v. (PTE-2.2) and PTE-3 at $1.4 \mathrm{mg} \mathrm{kg}^{-1}$ i.v. Injection of the mutants PTE-2.2 and PTE-3, 5 min after s.c. VX exposure, ensured survival and prevented severe signs of a cholinergic crisis. Inhibition of erythrocyte acetylcholinesterase (AChE) could not be prevented. However, medulla oblongata and diaphragm AChE activity was partially preserved. All animals treated with the wild-type enzyme, PTE-1, showed severe cholinergic signs and died during the observation period of $180 \mathrm{~min}$. PTE-2.1 resulted in the survival of all animals, yet accompanied by severe signs of OP poisoning. This study demonstrates for the first time efficient detoxification in vivo achieved with low doses of heterodimeric PTE-2 as well as PTE-3 and indicates the suitability of these engineered enzymes for the development of highly effective catalytic scavengers directed against VX.
\end{abstract}

Keywords Acetylcholinesterase $\cdot$ Catalytic bioscavenger $\cdot$ Detoxification $\cdot$ Enzyme engineering $\cdot$ In vivo . Organophosphate $\cdot$ PASylation $\cdot$ Phosphotriesterase $\cdot$ Therapy $\cdot$ VX

\section{Introduction}

Despite ban by the Chemical Weapons Convention, highly toxic organophosphorus nerve agents (OP) were repeatedly used in military conflicts, terrorist attacks or assassination

Timo Wille

timowille@bundeswehr.org

1 Bundeswehr Institute of Pharmacology and Toxicology, Neuherbergstraße 11, 80937 Munich, Germany

2 Chair of Biological Chemistry, Technical University of Munich, Emil-Erlenmeyer-Forum 5, 85354 Freising, Germany

3 Institute of Pharmacology, Toxicology and Pharmacy, Ludwig-Maximilians-University Munich, Königinstraße 16, 80539 Munich, Germany attempts. The use of sarin in the Syrian civil war, the supposed VX poisoning of Kim Jong Nam 2017 as well as the homicidal attacks of Sergei Skripal 2018 and of Alexei Navalny 2020 with novichok underline the persistent threat of these vicious compounds (Berlinger 2017; Dewan and Alkashli 2017; Halasz et al. 2020; John et al. 2018; Steindl et al. 2021; Vale et al. 2018).

The high toxicity of OP results from covalent binding to and subsequent inhibition of the pivotal enzyme acetylcholinesterase (AChE). This leads to a synaptic overflow of acetylcholine (ACh), followed by overstimulation and desensitization of muscarinic and nicotinic cholinergic receptors causing a broad spectrum of clinical signs including miosis, salivation and cardiac arrhythmia (Aldridge and Davison 1953; Aldridge and Reiner 1972; Holmstedt 1959). Ultimately, central and peripheral 
respiratory depression may lead to death by asphyxia (Thiermann et al. 2013; Yanagisawa et al. 2006).

For the past 60 years the standard therapy of OP poisoning has been a combination of the competitive muscarinic receptor antagonist atropine and an oxime as $\mathrm{AChE}$ reactivator (Cannard 2006; Thiermann et al. 2013). However, multiple in vitro and in vivo studies have shown that this treatment has limited effectiveness against different OP and cannot prevent cholinergic signs (Thiermann et al. 2013; Worek and Thiermann 2013). This triggered extensive research on enzyme-based scavengers to detoxify OP via hydrolysis to less toxic products in the blood compartment, thus preventing the distribution into target tissues and reducing toxicity (Masson and Nachon 2017; Worek et al. 2016a).

Phosphotriesterase (PTE) from Brevundimonas diminuta has emerged as a promising candidate for a catalytic bioscavenger (Masson and Rochu 2009; Worek et al. 2016a). Several research groups described PTE variants with improved catalytic activity, broadened substrate spectrum and stereopreference towards the more toxic $\mathrm{P}(-)$ nerve agent enantiomer (Bigley et al. 2013, 2015; Cherny et al. 2013; Goldsmith et al. 2017; Worek et al. 2016a). Hereby, a main focus was to improve the detoxification of highly toxic and biologically stable V-agents such as VX (Benschop and de Jong 1988; Masson and Nachon 2017; Reiter et al. 2015).

In fact, post-exposure therapy of $\mathrm{VX}$ poisoned guinea pigs with the engineered PTE mutant C23 $\left(k_{\mathrm{cat}} / K_{\mathrm{M}}=5 \times 10^{6} \mathrm{M}^{-1} \mathrm{~min}^{-1}\right)$ ensured survival and prevented systemic cholinergic toxicity (Worek et al. 2014), indicating that PTE variants may have the potential for use as pre- and post-exposure prophylaxis as well as post-exposure treatment (Worek et al. 2016b). Another improved mutant, the PTE variant C23AL detoxified VX with $k_{\text {cat }} / K_{\mathrm{M}}=12 \times 10^{6} \mathrm{M}^{-1} \mathrm{~min}^{-1}$, but in vivo data showed slower kinetics than the expected breakdown of VX extrapolated from in vitro data (Wille et al. 2016).

Theoretical calculations by Ashani et al. (2016) and Worek et al. (2016a) suggest a catalytic enzyme activity of $>50 \times 10^{6} \mathrm{M}^{-1} \mathrm{~min}^{-1}$ as a prerequisite for a practically applicable enzyme dose of $\leq 1 \mathrm{mg} \mathrm{kg}^{-1}$ body weight to achieve a VX degradation half-life $<5$ s for sufficient detoxification. Therefore, new mutants were recently engineered based on previously published variants C23 (Cherny et al. 2013), 10-2-C3 and 10-2-C3-I106A (Goldsmith et al. 2017).

Novel variants were generated to improve catalytic efficacy and stability, e.g. by replacing two unpaired Cys residues by the more inert amino acid Val (Job et al. 2020) or by creating a highly effective PTE heterodimer with broadened substrate spectrum (Escher et al. 2020). These two promising mutants were optimized with regard to extended plasma half-life with an additional C-terminal PAS-tag (Schlapschy et al. 2013) and showed efficient detoxification in vitro towards a broad substrate spectrum of structurally diverse nerve agents (Köhler et al. 2021).

Consequently, we have now set out to test the efficacy of the two novel PTE mutants, PTE-2 and PTE-3 (Table 1), in comparison with wild-type PTE (PTE-1) in a post-exposure therapy model of VX exposed rats.

\section{Materials and methods}

\section{Chemicals}

The OP VX ( $O$-ethyl S-(diisopropylaminoethyl)phosphonothioate; $>98 \%$ by ${ }^{1} \mathrm{H}$ and ${ }^{31} \mathrm{P}$ NMR $)$ and VR $(O$-isobutyl S-(diethylaminoethyl)phosphonothioate; $>98 \%$ by ${ }^{1} \mathrm{H}$ and ${ }^{31} \mathrm{P}$ NMR) were made available by the German Ministry of Defence. VX and VR stock solutions (1\% v/v in acetonitrile) were stored at room temperature. For each in vivo test, a fresh VX working solution $\left(36 \mu \mathrm{gL}^{-1}\right)$ was prepared in saline and put on ice until use. For the stereoselective analytics of VX in rat blood samples a VR working solution $\left(20 \mathrm{ng} \mathrm{mL}^{-1}\right)$ was prepared in acetonitrile as internal standard.

Tris[hydroxymethyl]-aminomethane (TRIS), Triton X-100, 5,5'-dithiobis(2-nitrobenzoic acid) (DTNB), acetylthiocholine iodide (ATCh), and ethopropazine were purchased from Sigma-Aldrich (Taufkirchen, Germany). Human erythrocyte acetylcholinesterase (AChE) was prepared from heparinized whole blood according to Bierwisch et al. (2014), Dodge et al. (1963), Worek et al. (2002). All other chemicals were purchased from Merck (Darmstadt, Germany).

\section{Protein expression and purification}

PTE-1, PTE-2, and PTE-3 (Table 1) were expressed in Escherichia coli using previously described plasmids according to published procedures by Escher et al. (2020),

Table 1 Overview of PTE variants tested in vivo

\begin{tabular}{|c|c|c|}
\hline & Variant & Molecular mass (Da) \\
\hline PTE-1 & Wild-type PTE ${ }^{\mathrm{a}, \mathrm{b}}$ & $37,617.9^{\mathrm{e}}$ \\
\hline PTE-2 & $\begin{array}{l}\text { PTE-C23(R152E)-PAS(100)-10-2- } \\
\text { C3(I106A/C59V/C227V/E71K)- } \\
\text { PAS(200) }\end{array}$ & $98,502.3$ \\
\hline PTE-3 & $10-2-\mathrm{C} 3(\mathrm{C} 59 \mathrm{~V} / \mathrm{C} 227 \mathrm{~V})-\mathrm{PAS}(200)^{\mathrm{b}, \mathrm{c}}$ & $54,075.9^{\mathrm{e}}$ \\
\hline \multicolumn{3}{|c|}{${ }^{\mathrm{a} C}$ Caldwell and Raushel (1991) } \\
\hline \multicolumn{3}{|c|}{${ }^{\mathrm{b}}$ Job et al. (2020) } \\
\hline \multicolumn{3}{|c|}{${ }^{\mathrm{c}}$ Köhler et al. (2021) } \\
\hline \multicolumn{3}{|c|}{${ }^{\mathrm{d}}$ Escher et al. (2020) } \\
\hline
\end{tabular}


Job et al. (2020) and Köhler et al. (2021). For production of PTE-1, E. coli BL21 was transformed with the expression plasmid encoding wild-type-PTE, whose synthetic gene was inserted between the KasI and HindIII restriction sites on pASK-IBA5(+) (IBA, Göttingen, Germany), including an N-terminal Strep-tag II (Schmidt and Skerra 2007). The bacteria were cultivated at $22{ }^{\circ} \mathrm{C}$ in shake flasks with $2 \mathrm{~L} \mathrm{~TB}$ medium $\left(0.017 \mathrm{~mol} \mathrm{~L}^{-1} \mathrm{KH}_{2} \mathrm{PO}_{4}, 0.072 \mathrm{~mol} \mathrm{~L}^{-1} \mathrm{~K}_{2} \mathrm{HPO}_{4}\right.$, $12 \mathrm{~g} \mathrm{~L}^{-1}$ Bacto tryptone, $24 \mathrm{~g} \mathrm{~L}^{-1}$ Bacto yeast extract, $4 \mathrm{ml} \mathrm{L}^{-1}$ glycerol) containing ampicillin $\left(100 \mathrm{mg} \mathrm{L}^{-1}\right)$ and $\mathrm{ZnSO}_{4}\left(0.2 \mathrm{mmol} \mathrm{L}^{-1}\right)$. Recombinant gene expression was induced at $\mathrm{OD}_{550} \approx 1.8-2.2$ by adding anhydrotetracycline $\left(200 \mu \mathrm{g} \mathrm{L}^{-1}\right)$ for up to $15 \mathrm{~h}$. Bacteria were harvested by centrifugation $\left(40 \mathrm{~min}, 5016 \times g, 4{ }^{\circ} \mathrm{C}\right)$, resuspended in $3 \mathrm{~mL}$ affinity chromatography buffer $\left(100 \mathrm{mmol} \mathrm{L}^{-1}\right.$ TRIS/ $\mathrm{HCl}, 150 \mathrm{mmol} \mathrm{L}^{-1} \mathrm{NaCl}, 10 \mathrm{mmol} \mathrm{L}^{-1} \mathrm{NaHCO}_{3}, 0.1 \mathrm{mmol}$ $\mathrm{L}^{-1} \mathrm{ZnSO}_{4}$, pH 8.0) per $1 \mathrm{~g}$ wet weight and mechanically disrupted using a high-pressure homogenizer (PandaPLUS 2000; GEA Niro Soavi, Lübeck, Germany). The soluble extract was loaded onto a Strep-Tactin column for affinity purification as described (Schmidt and Skerra 2007), followed by dialysis overnight against $20 \mathrm{mmol} \mathrm{L}^{-1}$ Hepes/ $\mathrm{NaOH}, 20 \mathrm{mmol} \mathrm{L}^{-1} \mathrm{NaCl}, 10 \mu \mathrm{mol} \mathrm{L}^{-1} \mathrm{ZnSO}_{4} \mathrm{pH} 7.2$ for PTE-1 and against $20 \mathrm{mmol} \mathrm{L}^{-1}$ Bis-Tris/HCl, $20 \mathrm{mmol}$ $\mathrm{L}^{-1} \mathrm{NaCl}, 10 \mu \mathrm{mol} \mathrm{L}^{-1} \mathrm{ZnSO}_{4} \mathrm{pH} 6.0$ for PTE-3. To remove endotoxin, the homodimeric PTE variants were loaded onto a $6 \mathrm{~mL}$ Resource $\mathrm{Q}$ anion exchange column (ResQ; Cytiva, Freiburg, Germany) equilibrated with the dialysis buffer. The protein was collected from the flow through and wash fractions. To remove the oligomers of the PTE-2, an anionexchange chromatography (AEX) was applied using a $6 \mathrm{~mL}$ ResQ column (Cytiva, Freiburg, Germany) equilibrated with $20 \mathrm{mmol} \mathrm{L}{ }^{-1}$ Hepes/NaOH, $20 \mathrm{mmol} \mathrm{L}^{-1} \mathrm{NaCl}, 10 \mu \mathrm{mol}$ $\mathrm{L}^{-1} \mathrm{ZnSO}_{4}$ at $\mathrm{pH}$ 7. The different species were separated by a linear concentration gradient from 20 to $250 \mathrm{mmol} \mathrm{L}^{-1}$ $\mathrm{NaCl}$ in running buffer over 20 column volumes. All PTEs were subjected to size-exclusion chromatography (SEC) on a $120 \mathrm{~mL}$ HiLoad Superdex 200 16/60 prep grade column or $320 \mathrm{ml}$ HiLoad Superdex 200 26/60 prep grade column (GE Healthcare, Freiburg, Germany) for final purification and buffer exchange using $50 \mathrm{mmol} \mathrm{L}{ }^{-1}$ TRIS/ $\mathrm{HCl}, 100 \mathrm{mmol}$ $\mathrm{L}^{-1} \mathrm{NaCl}, 10 \mu \mathrm{mol} \mathrm{L}{ }^{-1} \mathrm{ZnSO}_{4} \mathrm{pH} 8.0$ as running buffer. Endotoxin contents were determined using an EndosafePTS system (Charles River Laboratories, Wilmington, MA, USA) and were below $15 \mathrm{EU} \mathrm{mg}^{-1}$ for all proteins. Protein concentrations were quantified using an Ultrospec 2100 pro UV-Vis spectrophotometer (Cytiva, Freiburg, Germany) with a molar absorption coefficient at $280 \mathrm{~nm}$ calculated according to Wilkins et al. (1998). Protein purity was determined using SDS/PAGE (Coomassie-stained sodium dodecyl sulfate polyacrylamide gel electrophoresis) using the buffer system of Fling and Gregerson (1986) to be $>99 \%$ for all enzyme variants.

\section{Activity measurement of PTE enzymes}

The organophosphorus hydrolysis (OPH) rate of VX by the PTE mutant 1 was quantified in vitro as described by Goldsmith et al. (2016), Job et al. (2020), and Köhler et al. (2021). PTE-1 was incubated at $37^{\circ} \mathrm{C}$ with VX in $50 \mathrm{mmol}$ $\mathrm{L}^{-1}$ TRIS/HCl, $50 \mathrm{mmol} \mathrm{L}^{-1} \mathrm{NaCl}, \mathrm{pH} 8.0$ (final concentrations in a total volume of $600 \mu \mathrm{L}$ : PTE- $19.8 \times 10^{-6} \mathrm{~mol}$ $\mathrm{L}^{-1}$ and VX $\left.3.3 \times 10^{-6} \mathrm{~mol} \mathrm{~L}^{-1}\right)$. At defined time points $(1,7,14,20,30,45,60,90$, and $120 \mathrm{~min}), 50 \mu \mathrm{L}$ aliquots of this solution were added to an assay mixture (total volume; $3.15 \mathrm{~mL}$ ) containing acetylthiocholine (ATCh; $\left.0.45 \mathrm{mmol} \mathrm{L}^{-1}\right)$ and Ellman's reagent DTNB $(0.3 \mathrm{mmol}$ $\mathrm{L}^{-1}$ ) in $0.1 \mathrm{~mol} \mathrm{~L}^{-1}$ phosphate buffer (pH 7.4). To initiate the chromogenic reaction, $10 \mu \mathrm{L}$ AChE $(200 \mathrm{mE} / \mathrm{min}$ in phosphate buffer) was added and inhibition curves were recorded at $412 \mathrm{~nm}$ at $37{ }^{\circ} \mathrm{C}$ for $5 \mathrm{~min}$ using a UV-2600 photometer (Shimadzu, Kyoto, Japan). Pseudo-first order rate constants for $\mathrm{AChE}$ activity $k_{\mathrm{AChE}}\left(t_{\mathrm{OPH}}\right)$ and the $\mathrm{OPH}$ constant $k_{\mathrm{OPH}}$ were obtained and calculated as described by Job et al. (2020) and Köhler et al. (2021). $k_{\text {cat }} / K_{\mathrm{M}}$ of PTE-2 and PTE-3 were taken from Köhler et al. (2021).

\section{Animals}

Male Wistar rats (approximately $250-370 \mathrm{~g}$; corresponding to an age range of 7-9 weeks) were purchased from Charles River (Sulzfeld, Germany). In total, $n=65$ animals were used, five died during preparation. Prior to experiments, the animals were housed at least 7 days for acclimatization under controlled conditions (12 h light/ dark cycle [light from 7:00 a.m. to 7:00 p.m.], 20-24 ${ }^{\circ} \mathrm{C}$, 45-65\% humidity) with standard diet (Ssniff Spezialdiäten, Soest, Germany) and tap water ad libitum in eurostandard Makrolon cages type IV with heightened lids (Tecniplast, Hohenpeißenberg, Germany). For enrichment a house (Zoonlab, Castrop-Rauxel, Germany), embedding (Rettenmeier\&Söhne, Rosenberg, Germany), nestlets and wood wool (both from Zoonlab) were provided and replaced once a week. Every attempt was made to minimize discomfort and pain and to reduce the number of animals used in the study.

All experiments were in conformity with the German Animal Welfare Act of 18th May 2006 (BGBI. I S. 1206, 1313), the European Parliament and Council Directive of 22nd September 2010 (2010/63/EU) and carried out according to the Basel declaration as well as the $3 \mathrm{R}$ concept (replace, reduce, refine). The study was ethically approved by the institutional animal protection committee (Ref.-No. 42-34-30-40/G03-19). 


\section{Experimental procedure for PTE plasma concentration profile determination}

For PTE administration and blood sampling as shown in the time line (Fig. 1a), rats were repetitively anesthetized with short-time isoflurane inhalation (IsoFlo $100 \% \mathrm{w} / \mathrm{w}$, Abbott Laboratories, Burgdorf, Germany; oxygen as carrier gas), $5 \%$ for induction of anesthesia and $2 \%$ for maintenance. In advance to vascular cannulation, local anesthetic creme $\left(25 \mathrm{mg} \mathrm{g}^{-1}+25 \mathrm{mg} \mathrm{g}^{-1}\right.$ Prilocaine-Lidocaine; Pierre Fabre, Freiburg, Germany) was applied. To ensure an adequate depth of anesthesia, reflexes were checked regularly. Defined PTE doses were injected into the respective lateral tail vein using a peripheral intravenous inserted catheter (24 Gauge i.v. indwelling cannula, $0.7 \times 19 \mathrm{~mm}$; B. Braun, Melsungen, Germany) and flushed with saline before removal. Subsequently, blood samples were taken at various time points from the lateral tail vein over a period of $48 \mathrm{~h}$ (10 $\mathrm{min}, 20 \mathrm{~min}, 30 \mathrm{~min}, 60 \mathrm{~min}, 120 \mathrm{~min}, 240 \mathrm{~min}$, $480 \mathrm{~min}, 960 \mathrm{~min}, 1440 \mathrm{~min}$ and $2880 \mathrm{~min}$ ) with a maximum of five samples per animal. Sterile hypodermic needles were used to prick the vein and the blood samples were collected in heparinized Minivettes (POCT, Sarstedt, Nürmbrecht, Germany).

\section{Experimental groups for PTE plasma concentration profiles}

The animals ( $n=24$ ) were divided into three groups by simple randomization. PTE-1 was administered at a dose of $1.0 \mathrm{mg} \mathrm{kg}^{-1}$, the doses of PTE-2 and PTE-3 were adjusted according to the molecular weight to achieve equal

(a)

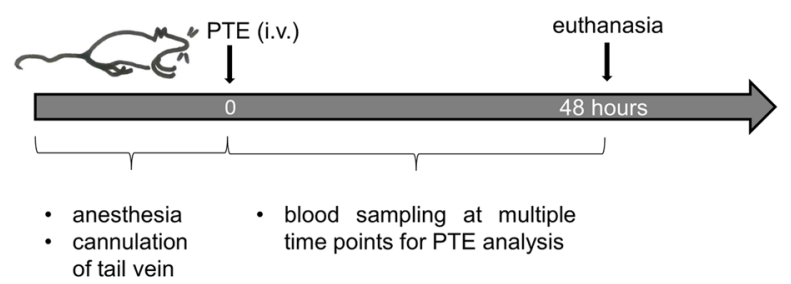

(b)

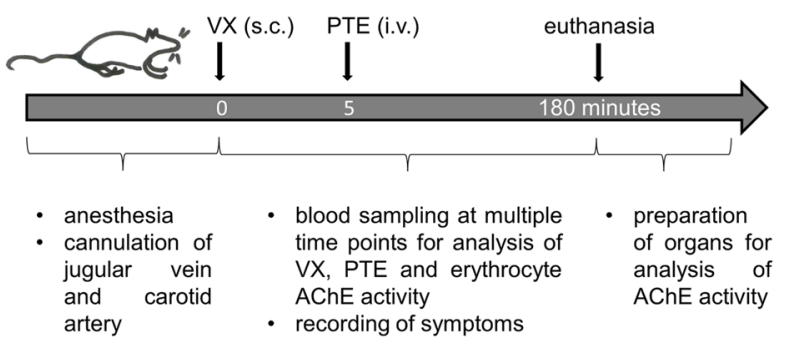

Fig. 1 Time lines for the determination of the PTE plasma profile (a) and the therapeutic efficacy study (b) stoichiometries (note that PTE-2 is a single-chain heterodimer with two distinct active sites) (Table 1).

- PTE-1 (1.0 $\mathrm{mg} \mathrm{kg}^{-1}$ i.v.; $\left.n=8\right)$.

- PTE-2 (1.3 $\mathrm{mg} \mathrm{kg}^{-1}$ i.v.; $\left.n=8\right)$.

- PTE-3 (1.4 $\mathrm{mg} \mathrm{kg}^{-1}$ i.v.; $\left.n=8\right)$.

\section{Experimental procedure for the therapeutic efficacy study}

Rats were anesthetized by i.m. injection of a mixture of medetomidine (0.15 $\mathrm{mg} \mathrm{kg}^{-1}$; Zoetis, Berlin, Germany), midazolam (0.4 $\mathrm{mg} \mathrm{kg}^{-1}$; Ratiopharm, Ulm, Germany) and fentanyl (0.1 mg kg${ }^{-1}$; Albrecht, Aulendorf, Germany) to reduce suffering from VX challenge. Reflexes were checked for depth of anesthesia throughout the whole experiment and anesthesia re-dosing was applied as required with 1/4-1/3 of the initial dose. Next, the animals were placed on a heatable operating table in supine position, a rectal thermistor was inserted and an electrocardiogram and a pulse oximeter were attached.

Eyes were covered with panthenol eye cream (Jenapharm Mibe, Brehna, Germany) to protect from dehydration. After preparation of the left a. carotis (for blood sampling) and the right $\mathrm{v}$. jugularis (for PTE injection), catheters $(24 \mathrm{G}$ $\times 3 / 4[0.7 \times 19 \mathrm{~mm}]$ Introcan; B. Braun) were inserted and fixed. The animals were monitored (blood pressure, heart rate, oxygenation, body temperature) throughout the whole experiment. Clinical signs were observed and heparinized blood samples ( $250 \mu \mathrm{L}$ replaced by Ringer's solution) were collected. The first blood sample was taken before and 11 further blood collections were scheduled between 3 and $180 \mathrm{~min}$ after subcutaneous injection of $25 \mu \mathrm{g} \mathrm{kg}^{-1}$ $\left(\sim 2 \mathrm{LD}_{50}\right)$ VX prepared in saline (Misik et al. 2015; Myhrer et al. 2015).

For AChE activity determination, $50 \mu \mathrm{L}$ whole blood was diluted (1:20) in distilled water, whereas $100 \mu \mathrm{L}$ whole blood was used for VX analysis. The remaining blood sample was centrifuged and plasma was used for PTE analysis. All samples were snap-frozen in liquid nitrogen and stored at $-80{ }^{\circ} \mathrm{C}$ until use. Directly after the end of the experiment tissue samples of diaphragm and medulla oblongata were taken and their wet weight determined. For the time line see Fig. 1b.

\section{Experimental groups for the therapeutic efficacy study}

The animals $(n=36)$ were divided into six groups by simple randomization:

- Solvent control group (saline i.v. 5 min after saline s.c.; $n=6)$. 
- VX control group (saline i.v. 5 min after $25 \mu \mathrm{g} \mathrm{kg}^{-1} \mathrm{VX}$ s.c.; $n=6)$.

- PTE-1 treatment group (1.0 $\mathrm{mg} \mathrm{kg}^{-1}$ PTE-1 i.v. 5 min after $25 \mu \mathrm{g} \mathrm{kg}^{-1}$ VX s.c.; $\left.n=8\right)$.

- PTE-2.1 treatment group $\left(1.3 \mathrm{mg} \mathrm{kg}^{-1}\right.$ PTE-2 i.v. 5 min after $25 \mu \mathrm{g} \mathrm{kg}^{-1}$ VX s.c.; $\left.n=4\right)$.

- PTE-2.2 treatment group (2.6 $\mathrm{mg} \mathrm{kg}^{-1}$ PTE-2 i.v. $5 \mathrm{~min}$ after $25 \mu \mathrm{g} \mathrm{kg}^{-1} \mathrm{VX}$ s.c.; $\left.n=4\right)$.

- PTE-3 treatment group (1.4 $\mathrm{mg} \mathrm{kg}^{-1}$ PTE-3 i.v. $5 \mathrm{~min}$ after $25 \mu \mathrm{g} \mathrm{kg}^{-1}$ VX s.c.; $\left.n=8\right)$.

\section{PTE analysis}

PTE concentrations in plasma samples were determined by means of the enzymatic activity via hydrolysis of paraoxonethyl (PXE) as a chromogenic substrate. For calibration curves of each PTE mutant, $2 \mu \mathrm{L}$ of the purified recombinant enzyme solution was diluted in TZN buffer $\left(50 \mathrm{mmol} \mathrm{L}^{-1}\right.$ TRIS/HCl, $10 \mu \mathrm{mol} \mathrm{L}^{-1} \mathrm{ZnSO}_{4}, 50 \mathrm{mmol} \mathrm{L}^{-1} \mathrm{NaCl}, \mathrm{pH}$ 8.0) and added to $48 \mu \mathrm{L}$ heparinized plasma from untreated rats up to final PTE concentrations between 1 and $10 \mu \mathrm{gL}^{-1}$. Plasma samples from the in vivo study were diluted in TZN buffer (PTE-1 and PTE-3, 1:5; PTE-2, 1:10). After incubation on ice for $2 \mathrm{~h}$, all samples were further diluted (PTE-1, 1:80; PTE-2, 1:20; PTE-3, 1:40) in TZN buffer. Then, 150 $\mu \mathrm{L}$ PXE substrate solution $\left(1 \mathrm{mmol} \mathrm{L}{ }^{-1}\right.$ in TZN buffer) was mixed each with $50 \mu \mathrm{L}$ sample solution in a 96-well plate (cell culture plate, 96-well, PS, flat bottom; Greiner BioOne, Frickenhausen, Germany). The change in absorbance at $400 \mathrm{~nm}$ was immediately recorded using an infinite M200 PRO plate reader (Tecan, Wien, Austria) at $25^{\circ} \mathrm{C}$ for $2 \mathrm{~min}$. The time-dependent absorbance of samples from the calibration curve and plasma were calculated in $\mathrm{mA} \mathrm{min}^{-1}$. Predetermined calibration curves were used for the calculation of the enzyme level in plasma samples. The corresponding circulation half-life (PTE $t_{1 / 2}$ ) was obtained using a onecompartment model with a mono-exponential decay of the calculated plasma enzyme levels versus the blood collection time points, and the maximal (initial) plasma concentration of PTE variants $\left(C_{\max }\right)$ was estimated by retrograde extrapolation of the mono-exponential curve fit using Prism Version 4.03 (GraphPad, San Diego, CA, USA).

\section{AChE activity assay}

Diaphragm and medulla oblongata were removed after the end of the experiment or death of the animal, snap-frozen in liquid nitrogen and stored at $-80{ }^{\circ} \mathrm{C}$ until the determination of the AChE activity.

Diaphragm was mixed with a tenfold volume of TRIS/HCl buffer (50 mmol L $\left.{ }^{-1}, \mathrm{pH} 7.4\right)$, supplemented with EDTA $\left(5 \mathrm{mmol} \mathrm{L}^{-1}\right)$ and $1 \%$ v/v Triton X-100 followed by homogenization of the mixture with a $\mathrm{T} 25$ digital ULTRA-TURRAX (IKA, Staufen, Germany). Medulla oblongata was mixed with a tenfold volume of phosphate buffer $\left(0.1 \mathrm{~mol} \mathrm{~L}^{-1}, \mathrm{pH} 7.4\right)$ containing $1 \%$ v/v Triton X-100. This mixture was subsequently homogenized with a glass-Teflon Potter (B. Braun). Afterwards, the homogenate was centrifuged (Microfuge 22; Hettich, Tuttlingen, Germany) at maximum speed for $5 \mathrm{~min}$. The supernatant was used to measure the AChE activity according to a modified Ellman assay (Worek et al. 1999). The total protein concentration was determined with a bicinchoninic acid assay (Protein Quantification Kit; Interchim Uptima, Montlucon, France) using bovine serum albumin as standard (Smith et al. 1985).

For analysis of all in vivo AChE activities polystrol cuvettes were filled with phosphate buffer $\left(0.1 \mathrm{~mol} \mathrm{~L}^{-1}\right.$, pH 7.4), $0.3 \mathrm{mmol} \mathrm{L}^{-1}$ DTNB and $0.02 \mathrm{mmol} \mathrm{L}^{-1}$ ethopropazine. After adding the sample the assay was started by adding $0.45 \mathrm{mmol} \mathrm{L}^{-1}$ ATCh and the absorbance change was recorded at $436 \mathrm{~nm}$ at $37{ }^{\circ} \mathrm{C}$ (Cary 50; Varian, Darmstadt, Germany). Erythrocyte AChE activity was referenced to the hemoglobin concentration of the respective blood dilution (Worek et al. 1999) and was calculated as $\mathrm{mU} \mu \mathrm{mol}^{-1} \mathrm{Hb}$. Diaphragm and brain AChE activity were referenced to the total protein concentration determined by the bicinchoninic acid method (Smith et al. 1985) and presented as $\mathrm{mU} \mathrm{mg}^{-1}$.

\section{Analysis of VX in blood samples}

VX enantiomers in blood samples were quantified by LC-MS/MS as described before (Reiter et al. 2008, 2011) with slight modifications. $100 \mu \mathrm{L}$ thawed, heparinized rat whole blood was diluted with $300 \mu \mathrm{L}$ water and mixed with $37.5 \mu \mathrm{L} 1 \mathrm{~mol} \mathrm{~L}^{-1}$ perchloric acid, followed by addition of $7.5 \mu \mathrm{L} 1 \mathrm{~mol} \mathrm{~L}^{-1}$ potassium acetate, and vortexed. The precipitated proteins were separated by centrifugation for $10 \mathrm{~min}$ at $21,290 \times g$ at $4{ }^{\circ} \mathrm{C}$. The supernatant was mixed with $50 \mu \mathrm{L}$ of $0.5 \%$ w/v ammonium hydroxide and $5 \mu \mathrm{L}$ of internal standard solution ( $20 \mathrm{ng} \mathrm{mL}^{-1}$ VR working solution prepared in acetonitrile) and centrifuged again for $3 \mathrm{~min}$ at $21,290 \times g$ at $4{ }^{\circ} \mathrm{C}$. The sample was applied to a preconditioned ( $1 \mathrm{~mL}$ methanol, $1 \mathrm{~mL}$ purified water; Milli-Q, Merck Millipore, Schwalbach, Germany) SPE cartridge (Strata-X PRP, 30 mg, $1 \mathrm{~mL}$; Phenomenex, Aschaffenburg, Germany) on a vacuum manifold. The column bed was rinsed with $1 \mathrm{~mL}$ water and carefully dried under maximum vacuum. The sample was eluted with $500 \mu \mathrm{L}$ acetonitrile and collected in a cup filled with $50 \mu \mathrm{L}$ purified water as keeper. The organic phase was evaporated in a vacuum rotation concentrator (50 min at room temperature) with $11,360 \times \mathrm{g}$ and the residue was reconstituted with $100 \mu \mathrm{L}$ purified water.

The analytical LC-MS/MS system for the quantification of VX enantiomers consisted of a Prominence HPLC system 
(Shimadzu Deutschland, Duisburg, Germany) and a QTRAP 6500 mass spectrometer (Sciex, Darmstadt, Germany).

Peak separation was achieved with a Chiralpak AGP column $(150 \times 2.1 \mathrm{~mm}, 5 \mu \mathrm{m}$, VWR, Darmstadt, Germany $)$ at a flow rate of $175 \mu \mathrm{L} \mathrm{min}{ }^{-1}$ using $25 \mathrm{mmol} \mathrm{L}^{-1}$ ammonium formate $(\mathrm{pH} 8.5)$ in water (eluent $\mathrm{A}$ ) and $25 \mathrm{mmol} \mathrm{L}^{-1}$ ammonium formate $(\mathrm{pH} 8.5)$ in 1:1 methanol-water (eluent B) with the following gradients: $90 \% \mathrm{~A}(0-3 \mathrm{~min}), 90-50 \%$ A (3-23 min), 50\% A (23-26 min), 50-90\% A (26-27 min), $90 \%$ A (27-30 min). The injection volume was $10 \mu \mathrm{L}$, applied at a column temperature of $30^{\circ} \mathrm{C}$.

Two MRM (multiple reaction monitoring) transitions each for VX and VR (internal standard) were selected for detection after positive electrospray ionization at $5.5 \mathrm{kV}$ with a source temperature of $400{ }^{\circ} \mathrm{C}$ and by applying the following declustering potentials and collision energies, respectively: $m / z, 268.1 \rightarrow 128.1(120,25), m / z, 268.1 \rightarrow 86.0$ $(146,32)$ for $\mathrm{VX}$ and $\mathrm{m} / \mathrm{z} 268.1 \rightarrow 100.1(120,25), \mathrm{m} / \mathrm{z}$ $268.1 \rightarrow 72.2(121,42)$ for VR.

Gas 1, gas 2, and curtain gas were set at $35,40,45$ arbitrary units. The entrance potential was set to $5.0 \mathrm{~V}$, cell exit potential was set to $12 \mathrm{~V}$. Dwell time was $750 \mathrm{~ms}$ and resolution was "unit" for both quadrupoles.

\section{Calculation of VX half-life}

The theoretical half-life of VX hydrolysis $\left(\mathrm{VX} t_{1 / 2}\right)$ was calculated by Eq. (1) according to Worek et al. (2016a) using in vitro $k_{\mathrm{cat}} / K_{\mathrm{M}}$ and the maximal plasma concentration of PTE variants $\left(C_{\max }\right)$ :

$\mathrm{VX} t_{1 / 2}=\frac{\ln (2)}{\frac{k_{\text {cat }}}{K_{\mathrm{M}}} \times C_{\max }}$

\section{Data analysis}

Data are shown as mean \pm standard deviation (SD). Data analysis and statistical comparisons were performed using Prism Version 5.04.

For the analysis of the diaphragm and medulla oblongata $\mathrm{AChE}$ activity differences between groups, a one-way repeated measure analysis of variance (ANOVA) with Bonferroni post-hoc test multiple comparison test was used. A $p<0.05$ value was considered to be statistically significant.

\section{Results}

\section{PTE plasma concentration profile in vivo}

As a prerequisite to study the protective effect of the newly engineered PTE enzymes, PTE-2 and PTE-3 in comparison

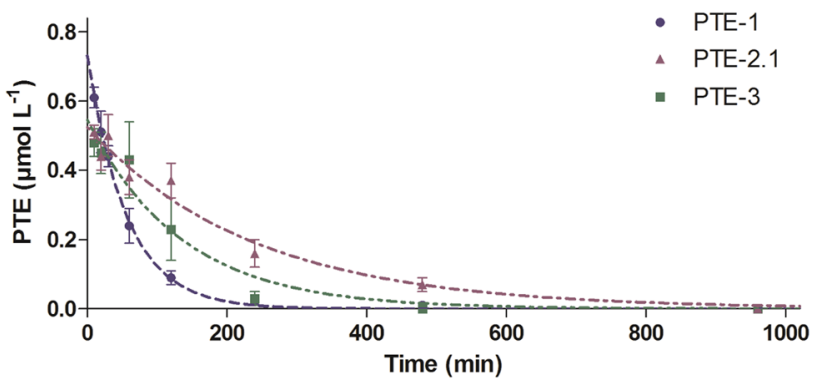

Fig. 2 PTE plasma concentration profile in rats over $48 \mathrm{~h}$ after injection of PTE-1 (1.0 mg kg${ }^{-1}$ i.v.), PTE-2 (1.3 mg kg-1 i.v.) or PTE-3 (1.4 $\mathrm{mg} \mathrm{kg}^{-1}$ i.v.)

Table 2 Calculated VX degradation by PTE variants

\begin{tabular}{lllll}
\hline Group & $\begin{array}{l}k_{\mathrm{cat}} / K_{\mathrm{M}} \\
\left(\mathrm{M}^{-1} \mathrm{~min}^{-1}\right)\end{array}$ & $C_{\max }\left(\mathrm{mol} \mathrm{L}^{-1}\right)$ & $t_{1 / 2}(\mathrm{~s})$ & $\begin{array}{l}\text { Time to } 96 \% \\
\text { VX degrada- } \\
\text { tion }(\mathrm{s})\end{array}$ \\
\hline PTE-1 & $0.02 \times 10^{6}$ & $5.7 \times 10^{-7}$ & 3632 & 18,200 \\
PTE-2.1 & $21 \times 10^{6}$ & $2.4 \times 10^{-7}$ & 8.2 & 41.1 \\
PTE-2.2 & $21 \times 10^{6}$ & $6.3 \times 10^{-7}$ & 3.1 & 15.7 \\
PTE-3 & $38 \times 10^{6}$ & $4.6 \times 10^{-7}$ & 2.4 & 11.8 \\
\hline
\end{tabular}

$C_{\max }$ was taken from the PTE plasma profile of the therapeutic efficacy study. Degradation half-life was calculated with Eq. (1) and time to $96 \% \mathrm{VX}$ degradation was estimated as $5 \times t_{1 / 2}$

to wild-type PTE-1, against VX exposure in rats their pharmacokinetics (PK) after i.v. injection was studied in the same species (Fig. 1a). PTE concentrations were analyzed according to the one compartment model, resulting in plasma half-life values (PTE $t_{1 / 2}$ ) of $39 \mathrm{~min}, 165 \mathrm{~min}$ and 94 min for PTE-1, PTE-2, and PTE-3, respectively (Fig. 2). As expected, the application of PASylation technology (Schlapschy et al. 2013) led to a considerable extension of the PK for PTE-2 and PTE-3. This effect was most pronounced for the single-chain heterodimeric enzyme PTE-2 which has its both subunits linked by a 100 residue PAS linker (Escher et al. 2020).

\section{Calculated VX hydrolysis}

From our previous studies, it was known that PTE-2 and PTE-3 show high catalytic efficiencies $\left(k_{\mathrm{cat}} / K_{\mathrm{M}}\right)$ towards VX hydrolysis in vitro (Table 2), which are by three orders higher than the one of wild-type PTE (PTE-1), whose $k_{\mathrm{cat}} / K_{\mathrm{M}}$ value of $0.02 \times 10^{6} \mathrm{M}^{-1} \mathrm{~min}^{-1}$ for $\mathrm{VX}$ was determined in the present study. The maximum PTE plasma concentrations $\left(C_{\max }\right)$, which were obtained from the PK analysis, allowed us to estimate half-lives of VX hydrolysis 
in vivo $\left(\mathrm{VX} t_{1 / 2}\right)$ which were below $10 \mathrm{~s}$ for the engineered enzymes but above $1 \mathrm{~h}$ for wild-type PTE (Table 2).

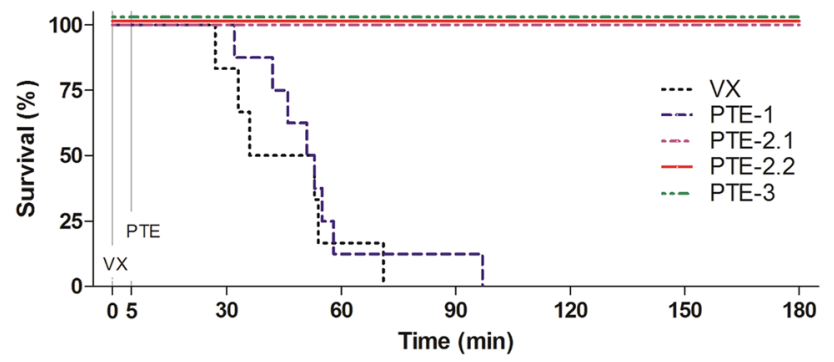

Fig. 3 Survival plot showing the survival of rats after VX exposure $\left(25 \mu \mathrm{g} \mathrm{kg}^{-1}\right.$ s.c.) without treatment, for the VX control group, and with PTE treatment (i.v.), 5 min after intoxication, for the groups PTE-1 (1.0 mg kg-1 i.v.), PTE-2.1 (1.3 $\mathrm{mg} \mathrm{kg}^{-1}$ i.v.), PTE-2.2 (2.6 $\mathrm{mg} \mathrm{kg}^{-1}$ i.v.) and PTE-3 (1.4 $\mathrm{mg} \mathrm{kg}^{-1}$ i.v.)

\section{Therapeutic efficacy study}

\section{Clinical signs and survival}

Subcutaneous injection of $25 \mu \mathrm{g} \mathrm{kg}^{-1}\left(\sim 2 \mathrm{LD}_{50}\right) \mathrm{VX}$ (Misik et al. 2015; Myhrer et al. 2015) resulted in signs of chewing and an early onset of local muscle fasciculations directly at the injection site in all animals of the VX control, PTE-1 and PTE-2.1 groups. Chewing was observed in one single animal each of the PTE-2.2 and PTE-3 groups and local fasciculations were seen directly at the VX injection site in two animals of the PTE-2.2 group and in five animals of the PTE-3 group (data not shown).

All degrees of convulsions, from uncontrolled muscle movements of head to forelimbs, hind legs and the entire body, were noted. Furthermore, respiratory distress was observed including the whole spectrum from labored breathing to respiratory depression. Over time, all animals of the VX control group and of the PTE-1 therapy group developed increasingly severe signs of a cholinergic crisis which persisted until death (Fig. 4). All animals of the VX

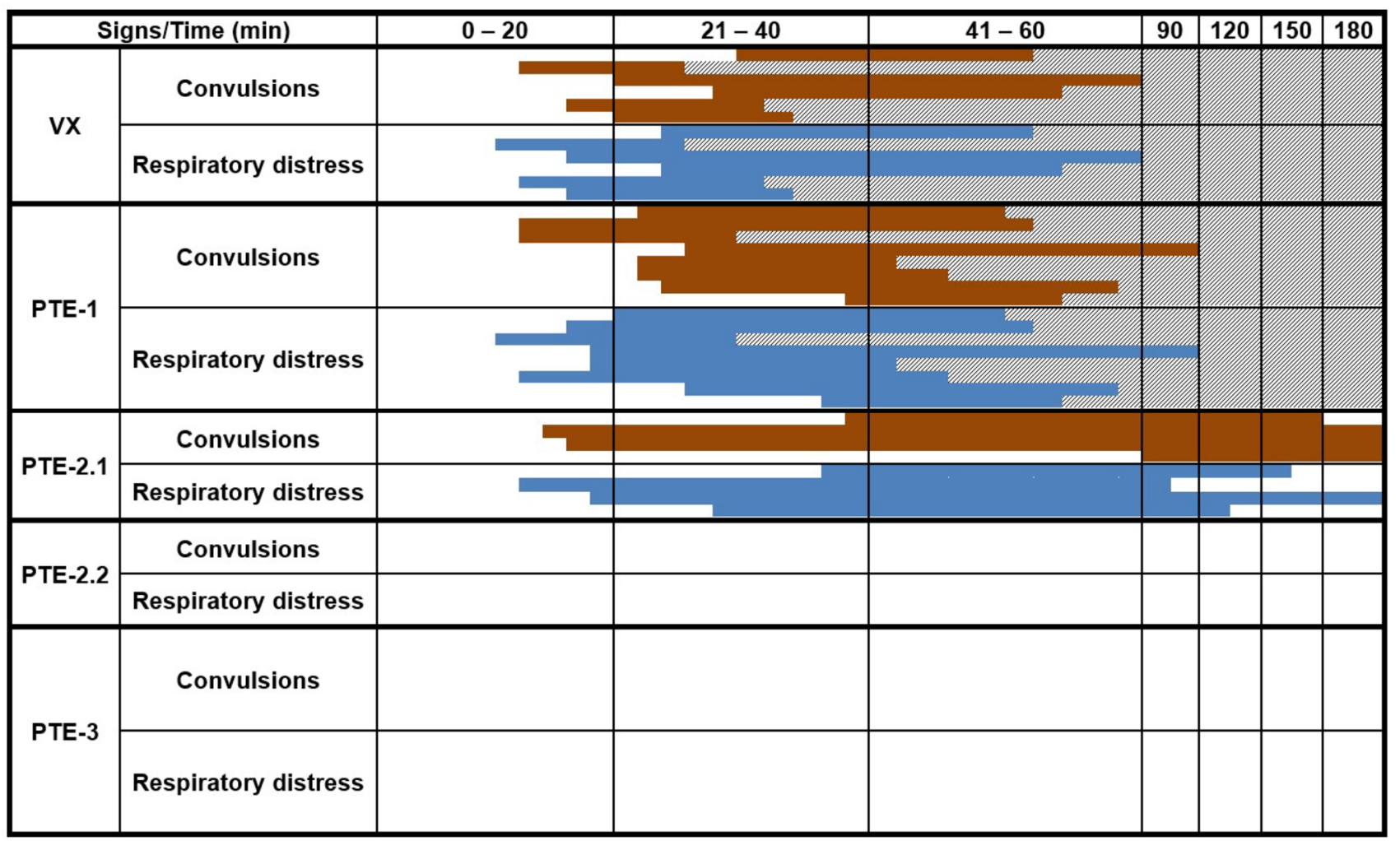

Fig. 4 Clinical signs and survival of VX exposed rats without treatment and with post-exposure treatment of PTE-1, PTE-2 and PTE3. Time of survival is given in minutes and each line represents an individual animal. Time of death is shown by grey, hatched lines. The signs are subdivided into convulsions (local, generalized) and respiratory distress (labored breathing, respiratory depression).
$25 \mu \mathrm{g} \mathrm{kg}^{-1} \mathrm{VX}$ s.c. (VX); $25 \mu \mathrm{g} \mathrm{kg}{ }^{-1} \mathrm{VX}$ s.c. followed after $5 \mathrm{~min}$ by $1.0 \mathrm{mg} \mathrm{kg}^{-1}$ PTE-1 i.v. (PTE-1); $25 \mu \mathrm{g} / \mathrm{kg}$ VX s.c. followed after 5 min by $1.3 \mathrm{mg} \mathrm{kg}^{-1}$ PTE-2 i.v. (PTE-2.1); $25 \mu \mathrm{g} \mathrm{kg}^{-1} \mathrm{VX}$ s.c. followed after $5 \mathrm{~min}$ by $2.6 \mathrm{mg} \mathrm{kg}^{-1}$ PTE-2 i.v. (PTE-2.2); $25 \mu \mathrm{g} \mathrm{kg}^{-1}$ VX s.c. followed after 5 min by $1.4 \mathrm{mg} \mathrm{kg}^{-1}$ PTE-3 i.v. (PTE-3) 
control group died between 27 and 71 min after subcutaneous VX injection (mean: $46 \pm 17 \mathrm{~min}$ ). The animals of the PTE-1 therapy group survived only slightly longer, between 32 and 97 min (mean: $54 \pm 19 \mathrm{~min}$ ) after s.c. VX injection (Fig. 3). In contrast, all rats treated with PTE-2.1, PTE-2.2 and PTE-3 survived until the end of the observation period of $180 \mathrm{~min}$ (Fig. 3). Only one of four VX poisoned rats treated with PTE-2.1 showed a longer-lasting dyspnea until the end of the observation period, whereas convulsions persisted in three of four rats (Fig. 4). Notably, none of the animals treated with PTE-2.2 and PTE-3 showed convulsions or respiratory distress as severe clinical signs throughout the experiment (Fig. 4).

\section{Erythrocyte AChE activity}

Erythrocyte AChE activities of animals prior to VX exposure and PTE treatment were $147 \pm 14 \mathrm{mU}_{\mu \mathrm{mol}^{-1} \mathrm{Hb}}$

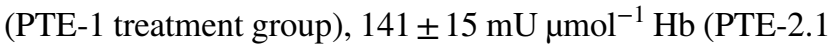
treatment group), $148 \pm 21 \mathrm{mU} \mu \mathrm{mol}^{-1} \mathrm{Hb}$ (PTE-2.2 treatment group), and $148 \pm 16 \mathrm{mU} \mu \mathrm{mol}^{-1} \mathrm{Hb}$ (PTE-3 treatment group). VX poisoning resulted in a rapid decrease of erythrocyte AChE activity in all groups and could not be prevented by administration of either PTE mutant (Fig. 5).

\section{Tissue AChE activity}

VX poisoning resulted in an almost complete inhibition of medulla oblongata and diaphragm AChE activity (Figs. 6,7). Therapy with PTE-1 had no protective effect whereas administration of PTE-2 and PTE-3 resulted in a partial preservation of AChE activity in these tissues. This effect was statistically significant in the PTE-2.2 and PTE-3 groups compared to VX and PTE-1 (Figs. 6, 7).

\section{VX blood concentration}

The quantification of VX enantiomers in whole blood samples revealed a rapid increase of (+)-VX and a delayed increase of the more toxic (-)-VX enantiomer (Fig. 8). In the VX control and PTE-1 treatment groups the concentration of both enantiomers increased during the further course of the experiment (Fig. 8). The analysis of (+)-VX in the VX control group showed a sharp increase in concentration up to $4.4 \mathrm{nmol} \mathrm{L}^{-1}$ within the first 6 min after VX administration and a maximum concentration of $5.4 \mathrm{nmol} \mathrm{L}^{-1}$. The (-)-VX concentration showed a delayed increase with $1.5 \mathrm{nmol} \mathrm{L}^{-1}$ at the sampling time $(6 \mathrm{~min})$ and a lower maximal concentration of $3.4 \mathrm{nmol} \mathrm{L}^{-1}$ (Fig. 8). In contrast, administration of PTE-2 and PTE-3 5 min after VX challenge resulted in an ongoing hydrolysis, resulting in lower concentrations of
(-)-VX (and (+)-VX) (Fig. 8). PTE-2.2 and PTE-3 treatment groups showed (+)-VX peak concentrations of $2.0 \mathrm{nmol} \mathrm{L}^{-1}$ and $1.9 \mathrm{nmol} \mathrm{L}^{-1}$, respectively, at $3 \mathrm{~min}$ with a subsequent decrease in concentration. The (-)-VX concentration exhibited only a very slight increase up to a maximum of $0.3 \mathrm{nmol}$ $\mathrm{L}^{-1}$ for the PTE-2.2 treatment group and $0.2 \mathrm{nmol} \mathrm{L}^{-1}$ for the PTE-3 treatment group at 3 min, with subsequent concentration below the quantification limit (Fig. 8).

\section{Discussion}

This study demonstrates the efficacy of post-exposure therapy of VX poisoned animals with the new PTE mutants PTE-2 and PTE-3. PTE- 3 is a hyperactive stabilized homodimeric enzyme (Job et al. 2020) carrying two PAS(200) tags (Schlapschy et al. 2013) whereas PTE-2 is a single-chain version with two distinct engineered active sites (Escher et al. 2020) whose two subunits are linked by a PAS(100) spacer and which is equipped with one PAS(200) tag (Table 1).

Efficient OP detoxification requires a sufficiently high catalytic activity, which can be determined in vitro $\left(k_{\mathrm{cat}} / K_{\mathrm{m}}\right)$. Previous studies have postulated that a $k_{\mathrm{cat}} / K_{\mathrm{m}}$ of at least $50 \times 10^{6} \mathrm{M}^{-1} \mathrm{~min}^{-1}$ is needed for successful therapy of VX poisoning at a reasonable enzyme dose of $1 \mathrm{mg} \mathrm{kg}^{-1}$ (Ashani et al. 2016; Worek et al. 2016a). Lower degradation rates or lower enzyme doses may still ensure survival but not prevent severe toxic effects.

Knowledge of the $k_{\text {cat }} / K_{\mathrm{m}}$ values and the PTE plasma concentration enables the calculation of VX degradation half-lives (Table 2) (Worek et al. 2014). Our results demonstrate that the recombinant wild-type PTE from Brevundimonas diminuta (PTE-1), with an in vitro $k_{\mathrm{cat}} / K_{\mathrm{m}}$ value of $0.02 \times 10^{6} \mathrm{M}^{-1} \mathrm{~min}^{-1}$, was ineffective in vivo to treat VX poisoning. Throughout the experiment the PTE-1 treatment group revealed increasingly severe toxic signs and circulatory depression (data not shown) similar to the VX control group (Fig. 4). Our findings for PTE-1 are in line with prior data from Masson and Rochu (2009) and Kolakowski et al. (1997), who determined a negligible protective effect of wild-type PTE against V-type nerve agents.

In contrast, the novel engineered enzyme PTE-3, with an in vitro $k_{\text {cat }} / K_{\mathrm{m}}$ of $38.1 \times 10^{6} \mathrm{M}^{-1} \mathrm{~min}^{-1}$, was able to prevent both mortality and severe toxicity in vivo. In comparison, the bispecific variant PTE-2, with an in vitro $k_{\text {cat }} / K_{\mathrm{m}}$ of $20.7 \times 10^{6} \mathrm{M}^{-1} \mathrm{~min}^{-1}$, was able to prevent mortality but not severe toxicity (convulsions, respiratory distress) at the initial dose of $1 \mathrm{mg} \mathrm{kg}^{-1}$ (Fig. 4). However, administration of a doubled PTE-2 dose was successful with regard to preventing severe toxic signs and ensuring survival. 


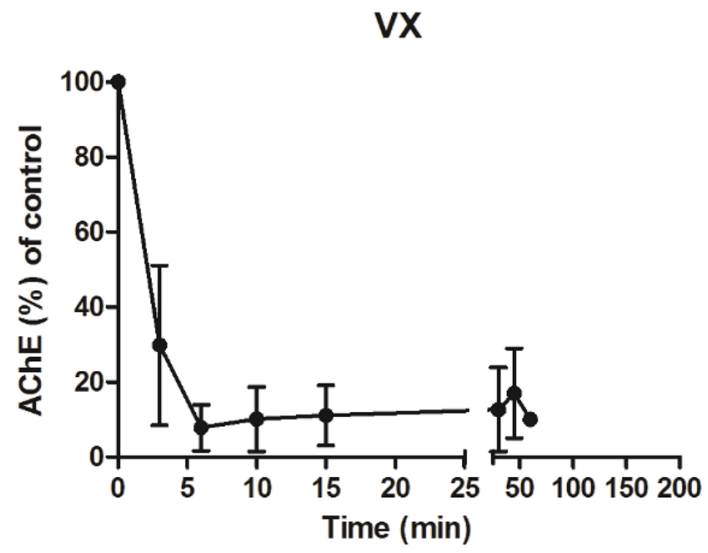

PTE-2.1

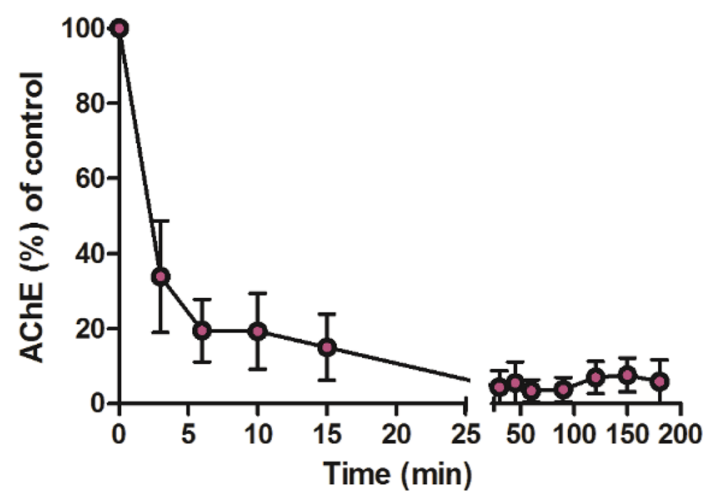

PTE-3

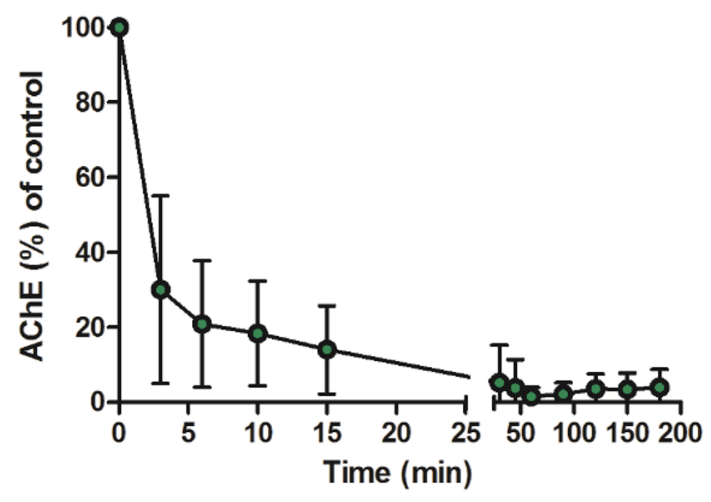

Fig. 5 Time-dependent changes of erythrocyte AChE activity. $25 \mu \mathrm{g} \mathrm{kg}^{-1} \mathrm{VX}$ s.c. (VX); $25 \mu \mathrm{g} \mathrm{kg} \mathrm{kX}^{-1} \mathrm{VX}$ s.c. followed after $5 \mathrm{~min}$ by $1.0 \mathrm{mg} \mathrm{kg}{ }^{-1}$ PTE-1 i.v. (PTE-1); $25 \mu \mathrm{g} \mathrm{kg}^{-1} \mathrm{VX}$ s.c. followed after $5 \mathrm{~min}$ by $1.3 \mathrm{mg} \mathrm{kg}^{-1}$ PTE-2 i.v. (PTE-2.1); $25 \mu \mathrm{g} \mathrm{kg}^{-1} \mathrm{VX}$ s.c. fol-

The therapeutic success of the PTE- 2 and PTE- 3 enzymes is mainly based on their high catalytic activities. Available $k_{\text {cat }} / K_{\mathrm{m}}$ values and PTE plasma concentrations allow a first approximation of the degradation half-time (Table 2). These data indicate a negligible VX degradation in a relevant time window by PTE-1, whereas PTE-2 (PTE-2.2) and PTE-3
PTE-1

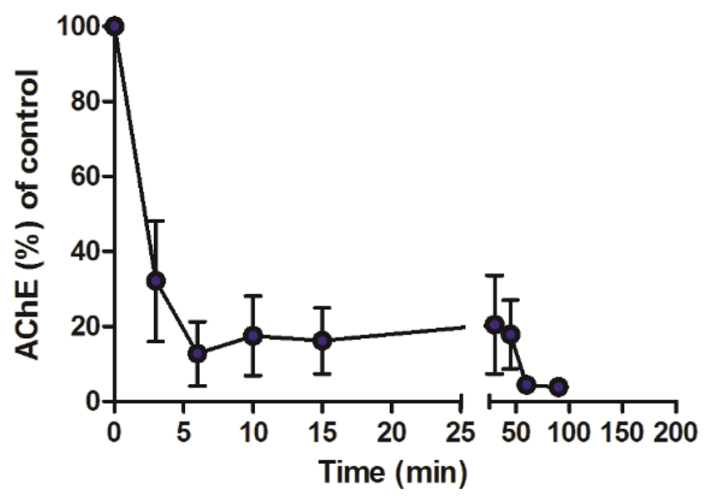

PTE-2.2

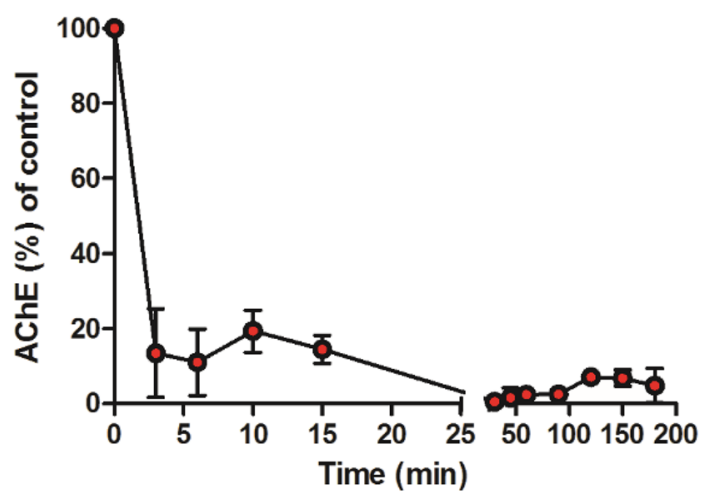

lowed after $5 \mathrm{~min}$ by $2.6 \mathrm{mg} \mathrm{kg}^{-1}$ PTE-2 i.v. (PTE-2.2); $25 \mu \mathrm{g} \mathrm{kg}^{-1}$ VX s.c. followed after 5 min by $1.4 \mathrm{mg} \mathrm{kg}^{-1}$ PTE-3 i.v. (PTE-3). Data are shown as $\%$ of solvent control activity (mean $\pm \mathrm{SD}$ )

show extremely short $t_{1 / 2}$ values of 3.1 and $2.4 \mathrm{~s}$, respectively. For a more detailed analysis, the extended circulation of the PASylated enzymes has to be taken into account, which further boosts the OP degradation as will be discussed below. 


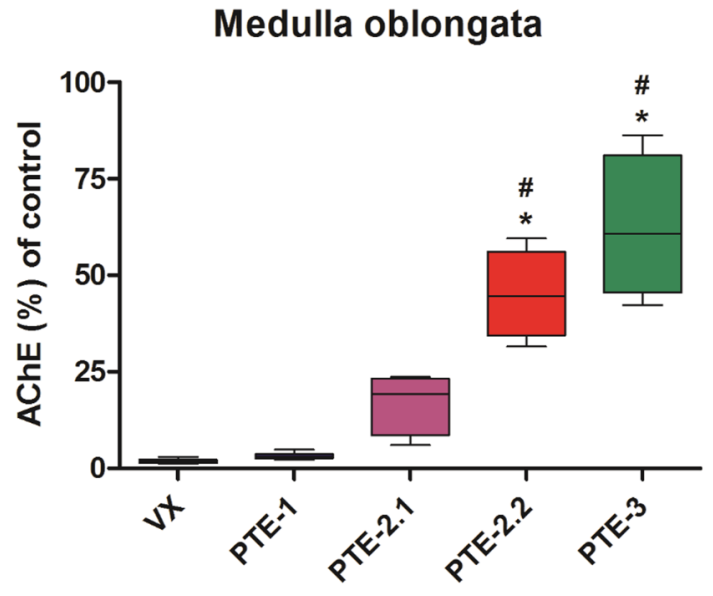

Fig. 6 Medulla oblongata AChE activity of the VX control group and the PTE-1, PTE-2, PTE-2.2 and PTE-3 treated rat groups. Data are presented as $\%$ of pre-exposure control AChE activity as mean values \pm SD using box plots with min to max whiskers. $\left({ }^{*} p<0.05\right.$ versus VX control group; ${ }^{\#} p<0.05$ versus PTE-1 group)

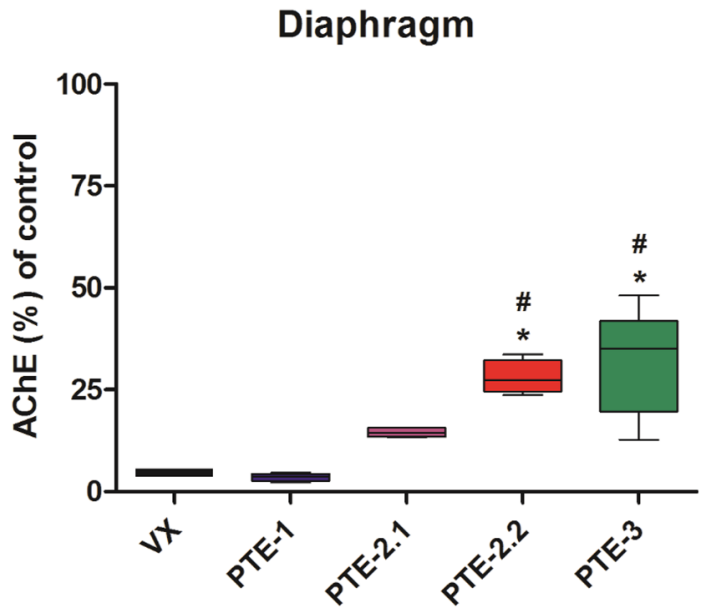

Fig. 7 Diaphragm AChE activity of the VX control group and the PTE-1, PTE-2, PTE-2.2 and PTE-3 treated rat groups. Data are presented as $\%$ of pre-exposure control AChE activity as mean values $\pm \mathrm{SD}$ using box plots with $\min$ to max whiskers. $\left({ }^{*} p<0.05\right.$ versus VX control group; ${ }^{\#} p<0.05$ versus PTE-1 group)

These theoretical considerations are supported by analyses of the VX enantiomer concentrations in vivo (Fig. 8). There was a gradual increase and persistence of both (-)and $(+)-\mathrm{VX}$ in the VX control and PTE-1 groups, whereas in the PTE-2 and PTE- 3 treatment groups (-)-VX levels were at or below the limit of quantification shortly after administration of PTE (Fig. 8). Notably, the (+)-VX level also decreased after PTE administration in these groups, which corresponds to previous in vitro data on the stereoselective degradation of VX by PTE-2 (BdPTE-7) and PTE-3 (BdPTE-4), showing a preferential but not exclusive hydrolysis of (-)-VX (Köhler et al. 2021).

The s.c. VX injection resulted in a delayed appearance of (-)-VX in the blood, relevant (-)-VX concentrations were first observed in the 6 min samples of the VX control and PTE-1 groups. This is in accordance with the slightly delayed inhibition of erythrocyte AChE activity and the emerging first signs of VX poisoning in the VX control group between 11 to 26 min (Fig. 4).

The difference in catalytic efficiency and therapeutic efficacy between the PTE variants is also reflected by AChE activities in the diaphragm and medulla oblongata (Figs. 6, 7). While a virtually complete AChE inhibition was observed in the VX control and PTE-1 groups, enzyme activity was partially preserved in the PTE-2 and PTE-3 groups. This indicates that distribution of VX from the central blood compartment into target tissues could not be fully prevented but was reduced substantially depending on the catalytic activity of the different PTE variants and/or concentrations, i.e. PTE-3 > PTE-2.2 > PTE-2.1 >> PTE-1.

Efficient detoxification requires not only a high catalytic activity of PTE but also a long biological half-life. This is of special importance in the case of VX and related agents since $\mathrm{V}$-agents exhibit a high biological stability and long persistence in vivo (Goldsmith et al. 2017; Reiter et al. 2011, 2015; van der Schans et al. 2003). In fact, in the case of VX poisoning current standard therapy with atropine and oxime must be administered over a prolonged period of time to preserve a sufficient level of active $\mathrm{AChE}$ and to ensure survival (Joosen et al. 2010). Hence, extension of the residence time of PTE in blood is the second key for a successful treatment. The PTE variants PTE-2 and PTE-3 were modified using PASylation technology (Binder and Skerra, 2017) in different ways, as explained above (Table 1). Plasma half-life of the unmodified wildtype PTE- 1 was only 39 min whereas PTE- 2 and PTE-3 showed a half-life of $165 \mathrm{~min}$ and $94 \mathrm{~min}$ (Fig. 2), respectively, which demonstrates that the PAS-tag has the ability to extend plasma half-life considerably. In fact, even more prolonged circulation can be expected when using longer PAS polypeptides, e.g. with 600 residues (Schlapschy et al. 2013; Binder and Skerra 2017; Gebauer and Skerra 2018).

The present study was based on anesthetized rats and s.c. administration of VX, which was due to animal welfare considerations and refinement at this stage of in vivo investigation. Further studies in conscious animals with percutaneous VX exposure are needed to verify the results and to more precisely evaluate required PTE doses and, potentially, the need for repeated PTE administration. Such studies are also needed to define the window of opportunity, i.e. the maximum time between agent exposure 
VX

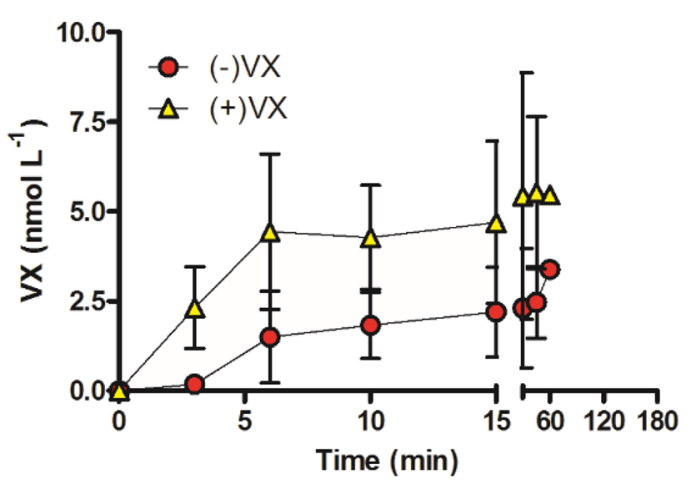

PTE-2.1

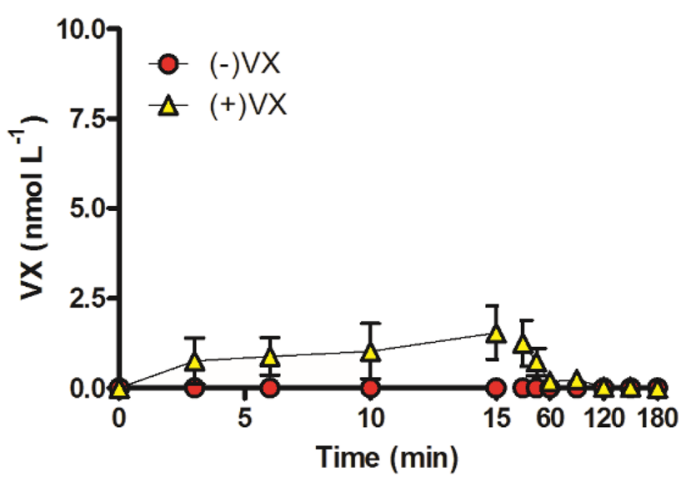

PTE-3

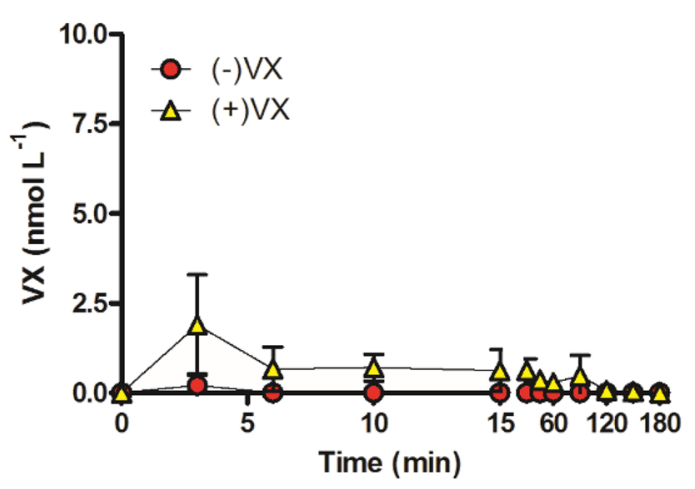

Fig. 8 Concentration of VX enantiomers in whole blood samples. $25 \mu \mathrm{g} \mathrm{kg}^{-1} \mathrm{VX}$ s.c. (VX); $25 \mu \mathrm{g} \mathrm{kg} \mathrm{k}^{-1} \mathrm{VX}$ s.c. followed after $5 \mathrm{~min}$ by $1.0 \mathrm{mg} \mathrm{kg}^{-1}$ PTE-1 i.v. (PTE-1); $25 \mu \mathrm{g} \mathrm{kg}^{-1} \mathrm{VX}$ s.c. followed after 5 min by $1.3 \mathrm{mg} \mathrm{kg}^{-1}$ PTE-2 i.v. (PTE-2.1); $25 \mu \mathrm{g} \mathrm{kg}^{-1} \mathrm{VX}$ s.c. fol-

and PTE administration without risking severe signs of toxicity.
PTE-1

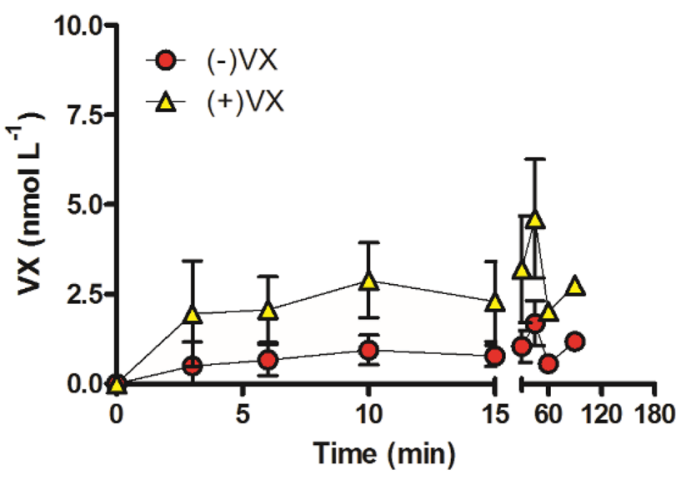

PTE-2.2

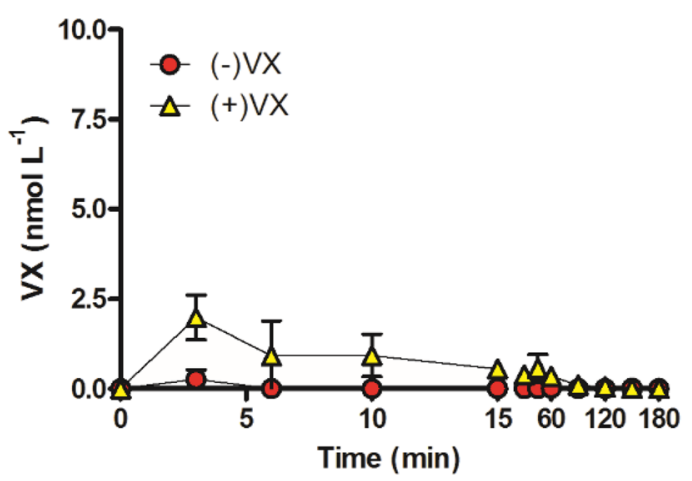

lowed after $5 \mathrm{~min}$ by $2.6 \mathrm{mg} \mathrm{kg}{ }^{-1}$ PTE-2 i.v. (PTE-2.2); $25 \mu \mathrm{g} \mathrm{kg}^{-1}$ VX s.c. followed after 5 min by $1.4 \mathrm{mg} \mathrm{kg}^{-1}$ PTE-3 i.v. (PTE-3). Data are given in $\mathrm{nmol} \mathrm{L}^{-1}$ per VX enantiomer as mean values $\pm \mathrm{SD}$

In conclusion, this study has demonstrated the potential of the engineered phosphotriesterases PTE-2 and PTE-3 as post-VX exposure treatment in order to prevent systemic 
toxicity and mortality. PASylation of PTE variants led to extended plasma half-life of these enzymes which is of special importance in the case of persistent nerve agents. Hence, the engineered PTE mutants PTE-2 and PTE-3 offer promising candidates as catalytic bioscavengers and deserve further investigation in vivo.

Acknowledgements The excellent technical assistance of N. Boos, N. Fiedler, S. Hänel, K. Kettner, L. Seck, A. Schröder, J. Schürger, M. Urban and A. Wosar is gratefully acknowledged.

Funding Open Access funding enabled and organized by Projekt DEAL.

\section{Declarations}

Conflict of interest A.S. is cofounder and shareholder of XL-protein $\mathrm{GmbH}$. All other authors declare that there are no conflicts of interest.

Open Access This article is licensed under a Creative Commons Attribution 4.0 International License, which permits use, sharing, adaptation, distribution and reproduction in any medium or format, as long as you give appropriate credit to the original author(s) and the source, provide a link to the Creative Commons licence, and indicate if changes were made. The images or other third party material in this article are included in the article's Creative Commons licence, unless indicated otherwise in a credit line to the material. If material is not included in the article's Creative Commons licence and your intended use is not permitted by statutory regulation or exceeds the permitted use, you will need to obtain permission directly from the copyright holder. To view a copy of this licence, visit http://creativecommons.org/licenses/by/4.0/.

\section{References}

Aldridge WN, Davison AN (1953) The mechanism of inhibition of cholinesterases by organophosphorus compounds. Biochem J 55(5):763-766. https://doi.org/10.1042/bj0550763

Aldridge WN, Reiner E (1972) Enzyme inhibitors as substrates: interactions of esterases with esters of organophosphorus and carbamic acids (Frontiers of Biology, 26). North-Holland Publ. Co, Amsterdam

Ashani Y, Leader H, Aggarwal N, Silman I, Worek F, Sussman JL, Goldsmith M (2016) In vitro evaluation of the catalytic activity of paraoxonases and phosphotriesterases predicts the enzyme circulatory levels required for in vivo protection against organophosphate intoxications. Chem Biol Interact 259(B):252-256. https:// doi.org/10.1016/j.cbi.2016.04.039

Benschop HP, de Jong LPA (1988) Nerve agent stereoisomers: analysis, isolation and toxicology. Acc Chem Res 21(10):368-374. https:// doi.org/10.1021/ar00154a003

Berlinger J (2017) VX nerve agent used to kill Kim Jong Nam, police say. CNN. https://edition.cnn.com/2017/02/23/asia/kim-jongnam-vx-nerve-agent/index.html. Accessed 28 Sep 2020

Bierwisch A, Zengerle M, Thiermann H, Kubik S, Worek F (2014) Detoxification of alkyl methylphosphonofluoridates by an oximesubstituted $\beta$-cyclodextrin - an in vitro structure-activity study. Toxicol Lett 224(2):209-214. https://doi.org/10.1016/j.toxlet. 2013.10.024

Bigley AN, Xu C, Henderson TJ, Harvey SP, Raushel FM (2013) Enzymatic neutralization of the chemical warfare agent VX: evolution of phosphotriesterase for phosphorothiolate hydrolysis. J Am
Chem Soc 135(28):10426-10432. https://doi.org/10.1021/ja402 $832 \mathrm{z}$

Bigley AN, Mabanglo MF, Harvey SP, Raushel FM (2015) Variants of phosphotriesterase for the enhanced detoxification of the chemical warfare agent VR. Biochemistry 54(35):5502-5512. https://doi. org/10.1021/acs.biochem.5b00629

Binder U, Skerra A (2017) PASylation ${ }^{\circledR}$ : a versatile technology to extend drug delivery. Curr Opin Colloid Interface Sci 31:10-17. https://doi.org/10.1016/j.cocis.2017.06.0004

Caldwell SR, Raushel FM (1991) Detoxification of organophosphate pesticides using a nylon based immobilized phosphotriesterase from Pseudomonas diminuta. Appl Biochem Biotechnol 31(1):59-73. https://doi.org/10.1007/BF02922126

Cannard K (2006) The acute treatment of nerve agent exposure. J Neurol Sci 249(1):86-94. https://doi.org/10.1016/j.jns.2006.06.008

Cherny I, Greisen P Jr, Ashani Y, Khare SD, Oberdorfer G, Leader H, Baker D, Tawfik DS (2013) Engineering V-type nerve agents detoxifying enzymes using computationally focused libraries. ACS Chem Biol 8(11):2394-2403. https://doi.org/10.1021/cb400 4892

Dewan A, Alkashli H (2017) Syria chemical attack: authority finds 'incontrovertible' evidence of Sarin. CNN. https://edition.cnn.com/ 2017/04/20/middleeast/syria-chemical-attack-sarin-opcw/index. html. Accessed 8 Jul 2021

Dodge JT, Mitchell C, Hanahan DJ (1963) The preparation and chemical characteristics of hemoglobin-free ghosts of human erythrocytes. Arch Biochem Biophys 100:119-130. https://doi.org/10. 1016/0003-9861(63)90042-0

Escher B, Köhler A, Job L, Worek F, Skerra A (2020) Translating the concept of bispecific antibodies to engineering heterodimeric phosphotriesterases with broad organophosphate substrate recognition. Biochemistry 59(45):4395-4406. https://doi.org/10.1021/ acs.biochem.0c00751

Fling SP, Gregerson DS (1986) Peptide and protein molecular weight determination by electrophoresis using a high-molarity tris buffer system without urea. Anal Biochem 155(1):83-88. https://doi.org/ 10.1016/0003-2697(86)90228-9

Gebauer M, Skerra A (2018) Prospects of PASylation ${ }^{\circledR}$ for the design of protein and peptide therapeutics with extended half-life and enhanced action. Bioorg Med Chem 26:2882-2887. https://doi. org/10.1016/j.bmc.2017.09.016

Goldsmith M, Eckstein S, Ashani Y, Greisen P Jr, Leader H, Sussman J, Aggarwal N, Ovchinnikov S, Tawfik D, Baker D, Thiermann H, Worek F (2016) Catalytic efficiencies of directly evolved phosphotriesterase variants with structurally different organophosphorus compounds in vitro. Arch Toxicol 90:2711-2724. https://doi.org/ 10.1007/s00204-015-1626-2

Goldsmith M, Aggarwal N, Ashani Y, Jubran H, Greisen PJR, Ovchinnikov S, Leader H, Baker D, Sussman JL, Goldenzweig A, Fleishman SJ, Tawfik DS (2017) Overcoming an optimization plateau in the directed evolution of highly efficient nerve agent bioscavengers. Protein Eng Des Sel 30(4):333-345. https://doi.org/10. 1093/protein/gzx003

Halasz S, Bryony Jones, Gianluca Mezzofiore (2020) Novichok nerve agent used in Alexey Navalny poisoning, says German government. CNN. https://edition.cnn.com/2020/09/02/europe/alexeynavalny-novichok-intl/index.html. Accessed 28 Sep 2020

Holmstedt B (1959) Pharmacology of organophosphorus cholinesterase inhibitors. Pharmacol Rev 11:567-688

Job L, Köhler A, Escher B, Worek F, Skerra A (2020) A catalytic bioscavenger with improved stability and reduced susceptibility to oxidation for treatment of acute poisoning with neurotoxic organophosphorus compounds. Toxicol Lett 321:138-145. https:// doi.org/10.1016/j.toxlet.2019.12.030

John H, van der Schans MJ, Koller M, Spruit HET, Worek F, Thiermann H, Noort D (2018) Fatal sarin poisoning in Syria 2013: 
Forensic verification within an international laboratory network. Forensic Toxicol 36(1):61-71. https://doi.org/10.1007/ s11419-017-0376-7

Joosen MJA, van der Schans MJ, van Helden HPM (2010) Percutaneous exposure to the nerve agent VX: efficacy of combined atropine, obidoxime and diazepam treatment. Chem Biol Interact 188(1):255-263. https://doi.org/10.1016/j.cbi.2010.06.010

Köhler A, Escher B, Job L, Koller M, Thiermann H, Skerra A, Worek F (2021) Catalytic activity and stereoselectivity of engineered phosphotriesterases towards structurally different nerve agents in vitro. Arch Toxicol 95:2815-2823. https://doi.org/10.1007/ s00204-021-03094-0

Kolakowski JE, Defrank JJ, Harvey SP, Szafraniec LL, Beaudry WT, Lai K, Wild JR (1997) Enzymatic hydrolysis of the chemical warfare agent VX and its neurotoxic analogues by organophosphorus hydrolase. Biocatal Biotransf 15(4):297-312. https://doi.org/10. 3109/10242429709003196

Masson P, Nachon F (2017) Cholinesterase reactivators and bioscavengers for pre- and post-exposure treatments of organophosphorus poisoning. J Neurochem 142(Suppl. 2):26-40. https://doi.org/10. 1111 /jnc. 14026

Masson P, Rochu D (2009) Catalytic bioscavengers: the next generation of bioscavenger-based medical countermeasures. In: Gupta R (ed) Handbook of toxicology of chemical warfare agents. Academic Press, London, pp 1053-1065

Misik J, Pavlikova R, Cabal J, Kuca K (2015) Acute toxicity of some nerve agents and pesticides in rats. Drug Chem Toxicol 38(1):3236. https://doi.org/10.3109/01480545.2014.900070

Myhrer T, Mariussen E, Enger S, Aas P (2015) Supralethal poisoning by any of the classical nerve agents is effectively counteracted by procyclidine regimens in rats. Neurotoxicology 50:142-148. https://doi.org/10.1016/j.neuro.2015.08.012

Reiter G, Mikler J, Hill I, Weatherby K, Thiermann H, Worek F (2008) Chromatographic resolution, characterisation and quantification of VX enantiomers in hemolysed swine blood samples. J Chromatogr B 873(1):86-94. https://doi.org/10.1016/j.jchromb.2008.08.001

Reiter G, Mikler J, Hill I, Weatherby K, Thiermann H, Worek F (2011) Simultaneous quantification of VX and its toxic metabolite in blood and plasma samples and its application for in vivo and in vitro toxicological studies. J Chromatogr B 879(26):27042713. https://doi.org/10.1016/j.jchromb.2011.07.031

Reiter G, Müller S, Hill I, Weatherby K, Thiermann H, Worek F, Mikler J (2015) In vitro and in vivo toxicological studies of $\mathrm{V}$ nerve agents: molecular and stereoselective aspects. Toxicol Lett 232(2):438-448. https://doi.org/10.1016/j.toxlet.2014.11.010

Schlapschy M, Binder U, Börger C, Theobald I, Wachinger K, Kisling S, Haller D, Skerra A (2013) PASylation: a biological alternative to PEGylation for extending the plasma half-life of pharmaceutically active proteins. Protein Eng Des Sel 26(8):489-501. https:// doi.org/10.1093/protein/gzt023

Schmidt TGM, Skerra A (2007) The Strep-tag system for one-step purification and high-affinity detection or capturing of proteins. Nat Protoc 2(6):1528-1535. https://doi.org/10.1038/nprot.2007.209

Smith PK, Krohn RI, Hermanson GT, Mallia AK, Gartner FH, Provenzano MD, Fujimoto EK, Goeke NM, Olson BJ, Klenk DC (1985) Measurement of protein using bicinchoninic acid. Anal Biochem 150:76-85. https://doi.org/10.1016/0003-2697(85)90442-7

Steindl D, Boehmerle W, Körner R, Praeger D, Haug M, Nee J, Schreiber A, Scheibe F, Demin K, Jacoby P, Tauber R, Hartwig
S, Endres M, Eckardt KU (2021) Novichok nerve agent poisoning. Lancet 397(10270):249-252. https://doi.org/10.1016/S01406736(20)32644-1

Thiermann H, Worek F, Kehe K (2013) Limitations and challenges in treatment of acute chemical warfare agent poisoning. Chem Biol Interact 206(3):435-443. https://doi.org/10.1016/j.cbi.2013. 09.015

Vale JA, Marrs TC, Maynard RL (2018) Novichok: a murderous nerve agent attack in the UK. J Toxicol Clin Toxicol 56(11):1093-1097. https://doi.org/10.1080/15563650.2018.1469759

van der Schans MJ, Lander BJ, van der Wiel H, Langenberg JP, Benschop HP (2003) Toxicokinetics of the nerve agent $( \pm)-V X$ in anesthetized and atropinized hairless guinea pigs and marmosets after intravenous and percutaneous administration. Toxicol Appl Pharmacol 191(1):48-62. https://doi.org/10.1016/S0041008X(03)00216-3

Wilkins MR, Gasteiger E, Tonella L, Ou K, Tyler M, Sanchez JC, Gooley AA, Walsh BJ, Bairoch A, Appel RD, Williams KL, Hochstrasser DF (1998) Protein identification with N and C-terminal sequence tags in proteome projects. J Mol Biol 278(3):599608. https://doi.org/10.1006/jmbi.1998.1726

Wille T, Neumaier K, Koller M, Ehinger C, Aggarwal N, Ashani Y, Goldsmith M, Sussman JL, Tawfik DS, Thiermann H, Worek F (2016) Single treatment of VX poisoned guinea pigs with the phosphotriesterase mutant C23AL: intraosseous versus intravenous injection. Toxicol Lett 258:198-206. https://doi.org/10. 1016/j.toxlet.2016.07.004

Worek F, Thiermann H (2013) The value of novel oximes for treatment of poisoning by organophosphorus compounds. Pharmacol Ther 139(2):249-259. https://doi.org/10.1016/j.pharmthera.2013. 04.009

Worek F, Mast U, Kiderlen D, Diepold C, Eyer P (1999) Improved determination of acetylcholinesterase activity in human whole blood. Clin Chim Acta 288(1-2):73-90. https://doi.org/10.1016/ S0009-8981(99)00144-8

Worek F, Reiter G, Eyer P, Szinicz L (2002) Reactivation kinetics of acetylcholinesterase from different species inhibited by highly toxic organophosphates. Arch Toxicol 76(9):523-529. https:// doi.org/10.1007/s00204-002-0375-1

Worek F, Seeger T, Reiter G, Goldsmith M, Ashani Y, Leader H, Sussman JL, Aggarwal N, Thiermann H, Tawfik DS (2014) Post-exposure treatment of VX poisoned guinea pigs with the engineered phosphotriesterase mutant C23: a proof-of-concept study. Toxicol Lett 231(1):45-54. https://doi.org/10.1016/j.toxlet.2014.09.003

Worek F, Thiermann H, Wille T (2016a) Catalytic bioscavengers in nerve agent poisoning: a promising approach? Toxicol Lett 244:143-148. https://doi.org/10.1016/j.toxlet.2015.07.012

Worek F, Thiermann H, Wille T (2016b) Oximes in organophosphate poisoning: 60 years of hope and despair. Chem Biol Interact 259(Pt B):93-98. https://doi.org/10.1016/j.cbi.2016.04.032

Yanagisawa N, Morita H, Nakajima T (2006) Sarin experiences in Japan: acute toxicity and long-term effects. J Neurol Sci 249(1):76-85. https://doi.org/10.1016/j.jns.2006.06.007

Publisher's Note Springer Nature remains neutral with regard to jurisdictional claims in published maps and institutional affiliations. 